\title{
Genetics of Cleft Lip and Cleft Palate
}

\author{
Elizabeth J. Leslie ${ }^{1,2}$ and Mary L. Marazita ${ }^{1,3}$ \\ ${ }^{1}$ Center for Craniofacial and Dental Genetics, Department of Oral Biology, University of \\ Pittsburgh, Pittsburgh, PA \\ ${ }^{2}$ Department of Biomedical Informatics, University of Pittsburgh, Pittsburgh, PA \\ ${ }^{3}$ Department of Human Genetics, University of Pittsburgh, Pittsburgh, PA
}

\begin{abstract}
Orofacial clefts are common birth defects and can occur as isolated, nonsyndromic events or as part of Mendelian syndromes. There is substantial phenotypic diversity in individuals with these birth defects and their family members: from subclinical phenotypes to associated syndromic features that is mirrored by the many genes that contribute to the etiology of these disorders. Identification of these genes and loci has been the result of decades of research using multiple genetic approaches. Significant progress has been made recently due to advances in sequencing and genotyping technologies, primarily through the use of whole exome sequencing and genomewide association studies. Future progress will hinge on identifying functional variants, investigation of pathway and other interactions, and inclusion of phenotypic and ethnic diversity in studies.
\end{abstract}

\section{Keywords}

Cleft lip; cleft palate; genetics; syndromes; nonsyndromic

\section{INTRODUCTION}

Orofacial clefts, notably cleft lip (CL) and cleft palate (CP), are the most common craniofacial birth defects in humans and represent a substantial personal and societal burden. Clefts affect approximately 1 in 700 individuals [Rahimov et al., 2012] with a lifetime cost of treatment estimated at $\$ 200,000$ [Berk and Marazita, 2002; Wehby and Cassell, 2010]. Affected individuals initially face difficulties feeding and also experience speech, hearing, and dental problems. Although clefts can be surgically repaired, patients often undergo multiple craniofacial and dental surgeries, as well as speech and hearing therapy. Despite these interventions, patients can experience lifelong psychosocial effects from the malformation. In fact, individuals born with a cleft have increased incidence of mental health problems and higher mortality rates at all stages of life [Christensen et al., 2004; Wehby and Cassell, 2010]. Clefting is also associated with a higher risk of various cancer types, including breast, brain, and colon cancers, in the individual with a cleft as well as their family members [Bille et al., 2005; Dietz et al., 2012; Menezes et al., 2009; Zhu et al., 2002]. The complications of clefting in early life are particularly devastating in developing countries where access to medical care may be limited [Wehby et al., 2006]. Understanding the etiologies of clefting is important not only for our knowledge of developmental biology,

Contact Person. Mary L. Marazita, Ph.D., Center for Craniofacial and Dental Genetics, University of Pittsburgh, Suite 500 Bridgeside Point, 100 Technology Dr, Pittsburgh, PA 15219, Ph: 412-648-8380, Fax: 412-648-8779, Marazita@ pitt.edu.

The authors have no conflicts of interest to declare. 
but ultimately for improved prevention, treatment, and prognosis for individuals affected by orofacial clefting.

\section{DEVELOPMENT OF OROFACIAL CLEFTS}

Orofacial clefts arise from failure of normal craniofacial developmental processes. Proper development of the face requires coordination of a complex series of events and includes cell growth, migration, differentiation, and apoptosis. The development of the face begins in the $4^{\text {th }}$ week of development when neural crest cells migrate to form the five facial primordia: the frontonasal prominence, the paired mandibular processes, and the paired maxillary processes $(\mathrm{MxP})$. After facial prominences are formed, the nasal placodes invaginate to form the medial (MNP) and lateral (LNP) nasal processes. During the $6^{\text {th }}$ and $7^{\text {th }}$ weeks of gestation, the LNP merge with the MxP and then fuse with the MNP, forming the upper lip and primary palate (reviewed by Jiang et al. [2006]). Failure in growth or fusion of these processes results in orofacial clefting involving the upper lip, alveolus, and/ or primary palate. The secondary palate begins to develop in the $7^{\text {th }}$ week of embryogenesis when the palatal shelves (PS) emerge as outgrowths from the MxP. The PS initially grow vertically along the sides of the developing tongue but later elevate into a horizontal position as the tongue flattens (reviewed by Gritli-Linde [2007]). Continued growth leads to the PS meeting at the midline followed by fusion along the medial edge epithelia (MEE). Successful fusion of the secondary palate results in complete separation of the nasal and oral cavities. Clefts of the palate can arise due to failure at any of several steps including PS elevation, migration, or fusion.

\section{OROFACIAL CLEFT PHENOTYPES}

Orofacial clefts are a heterogeneous group of disorders affecting the structure of the face and oral cavity that have been divided into three general categories: those that affect the lip only (CL, Fig 1A), those affecting the lip and palate (CLP, Fig 1B), and those affecting the palate alone (CP, Fig 1C). Historically, CL and CLP have been considered variants of the same defect that only differ in severity [Marazita, 2012]. Although the primary palate and secondary palate have distinct developmental origins, CL and CLP share a defect of the primary palate, motivating the inclusion of CL and CLP into a common group-cleft lip with or without cleft palate (CL/P) [Fogh-Andersen 1942; Fraser 1955]. However, epidemiological [Grosen et al., 2010] and biological [Ludwig et al., 2012; Rahimov et al., 2008] data suggest that CL and CLP may have separate genetic etiologies. Nonetheless, common pathways may underlie the etiologies of each group, as occasionally both CL/P and $\mathrm{CP}$ are present within the same pedigree. This event is often referred to as mixed clefting, and is most commonly noted in syndromic forms of clefting [Rahimov et al., 2012].

\section{SUBCLINICAL PHENOTYPES IN OROFACIAL CLEFT FAMILIES}

Despite the range of phenotypic presentations, orofacial clefts are typically thought of as a simple, qualitative trait (unaffected vs. affected). Recent evidence, however, suggests that individuals with clefts lie on a spectrum of overt phenotypes (CL, CLP, and CP) and a range of subclinical features, which may also be present in "unaffected" relatives of cases [Weinberg 2009]. These phenotypes include craniofacial measures [Weinberg et al., 2006], dental anomalies (tooth agenesis, microdontia, and supernumerary teeth) [Vieira et al., 2008], brain structural differences [Nopoulos et al., 2002; Weinberg et al., 2013], and dermatoglyphic lip print whorls [Neiswanger et al., 2009]. Subclinical phenotypes of the lip and palate include microform clefts (also known as congenital healed cleft lip), defects of the orbicularis oris muscle [Neiswanger, 2007; Rogers et al., 2008; Weinberg et al., 2008], bifid uvula, submucous cleft palate, and velopharyngeal insufficiency. These subclinical 
phenotypes may help explain incomplete penetrance or apparent lack of Mendelian inheritance patterns observed in families with overt clefts. Subclinical phenotypes might also explain an interesting phenomenon in discordant monozygotic twin pairs. Despite a lack of concordance, the recurrence risk for offspring of the affected and unaffected twin in discordant monozygotic twin pairs is largely identical [Grosen et al., 2011]. Subphenotypes and subclinical phenotypes are also important to consider in the design of genetic studies because power is reduced when diverse phenotypes of different etiologies are merged, Incorporation of such phenotypic distinctions allow more biologically relevant groupings.

\section{SYNDROMIC OROFACIAL CLEFTS}

The designation of orofacial clefts as syndromic is usually based on the presence of additional physical or cognitive abnormalities. At least 275 syndromes, in which clefting is a primary feature, have been identified (http://www.ncbi.nlm.nih.gov/OMIM) and these are caused by mutation of a single genetic locus, chromosomal abnormalities, or teratogens. Of the described syndromes, $75 \%$ have a known genetic cause, including hundreds of syndromes due to Mendelian inheritance at a single genetic locus (summarized in Table I).

Van der Woude syndrome (VWS; OMIM \#119300) is the most common form of syndromic clefting, accounting for approximately $2 \%$ of all CL/P cases, with a prevalence of $1 / 34,000$ live births [Burdick, 1986]. VWS and its allelic disorder popliteal pterygium syndrome (PPS; OMIM \#119500) are caused by mutations is IRF6 [Kondo et al., 2002]. Hundreds of mutations have been reported to cause these disorders, and while they are enriched in the DNA-binding domain of this transcription factor, they are also found throughout the proteinbinding domain [de Lima et al., 2009; Leslie et al., 2012b].

Most clefting syndromes are rare, affecting only one in several hundred thousand live births. Identification of genes causing these syndromes has been very successful [Dixon et al., 2011] and has been further facilitated by advances in sequencing technology. Exome sequencing recently identified genes causing Kabuki syndrome [ $\mathrm{Ng}$ et al., 2010a], Miller syndrome [Ng et al., 2010b], and Bartsocas-Papas syndrome [Kalay et al., 2012; Mitchell et al., 2012].

\section{NONSYNDROMIC OROFACIAL CLEFTS}

\section{Epidemiology}

The majority of orofacial cleft cases lack additional features and are categorized as "nonsyndromic", i.e., 70\% of all CL/P cases and 50\% of all CPO cases [Jugessur et al., 2009a]. Although many studies have reported the prevalence of CL/P, those that have distinguished CLP from CL observed that CLP is twice as common as CL [Jensen et al., 1988]. Among nonsyndromic clefts, $\mathrm{CL} / \mathrm{P}$ is twice as frequent in males than in females, while $\mathrm{CP}$ is twice as frequent in females [Mossey et al., 2009]. Approximately $75 \%$ of clefts involving the lip are unilateral. Among unilateral clefts, those affecting the left side are twice as common as right-sided clefts [Gundlach and Maus, 2006].

Interestingly, the prevalence of nonsyndromic cleft lip with or without cleft palate (NSCL/P) also varies by ancestry. NSCL/P most commonly affects those of Asian or Amerindian descent (1/500 live births) and least commonly those of African descent (1/2500) [Dixon et al., 2011]. Caucasian populations have an intermediate prevalence rate at approximately 1/1000 [Mossey et al., 2009]. The influence of socioeconomic status on prevalence of orofacial clefts has not been conclusively determined [Carmichael et al., 2003; Clark et al., 2003; Yang et al., 2008]. Possible explanations for the differences in prevalence among 
geographic origins and socioeconomic statuses include environmental factors such as vitamin use, nutrition, access to medical care, and lifestyle risk factors such as smoking.

\section{Evidence for genetic etiology in NSCL/P}

NSCL/P is a genetically complex disorder caused by the interaction of multiple genetic and environmental risk factors. Although the familiality of orofacial clefts has long been noted (see e.g. [Darwin, 1875; Sproule, 1863; Trew, 1757]), formal genetic studies did not begin until Fogh-Anderson [1942] proposed that genetic factors contribute to NSCL/P after observing an increased frequency of clefting in relatives of a patient with a cleft [FoghAndersen, 1942]. Segregation analysis [Marazita et al., 1984] and twin studies [Mitchell, 2002] later supported a genetic component to NSCL/P. NSCL/P has a high rate of family recurrence; the risk for $\mathrm{CL}$ in first degree relatives is estimated to be 32 times the risk for individuals without a family history of CL [Sivertsen et al., 2008]. The concordance rate of $40-60 \%$ in monozygotic twins is higher than the 3-5\% rate in dizygotic twins and also suggests a strong, but not purely, genetic etiology [Little and Bryan, 1986].

\section{Environmental Risk Factors}

Epidemiological data support a role for environmental risk factors in the development of orofacial clefts. Maternal smoking has been consistently associated with an increased risk of clefting, with a population-attributable risk estimated as high as $20 \%$ and an odds-ratio of 1.3 for CLP [Shi et al., 2008]. While alcohol is an established teratogen [West and Blake, 2005], evidence supporting a role for maternal alcohol use in clefting has been inconsistent [Murray, 2002]. However, some support for maternal alcohol consumption comes from an association between clefting and genetic variants in the alcohol dehydrogenase gene $\mathrm{ADH} H \mathrm{C}$ [Jugessur et al., 2009b]. Moreover, a recent study demonstrated that the combination of $A D H I C$ variants with reduced enzymatic activity and heavy maternal alcohol use increased the risk for orofacial clefts [Boyles et al., 2010]. However, a role for alcohol may be confounded by other risk factors such as nutrition, smoking, or stress that can be associated with alcohol consumption in some contexts.

Nutrition during pregnancy has been suggested as another contributing factor based on observational and interventional studies using folate supplements as a preventive measure [Wehby and Murray, 2010]. The beneficial effect of folate use, however, remains controversial and has not been consistently replicated [Wehby and Murray, 2010; Wilcox et al., 2007]. Other nutrients, including cholesterol [Porter, 2006], zinc [Munger et al., 2009], and general multivitamin use [Johnson and Little 2008] have also been studied, but need to be expanded to larger populations. Finally, other exposures to teratogens and environmental toxins have also been associated with increased risk of clefting [Abbott, 2010] such as retinoic acid, valproic acid, and phenytoin. A more comprehensive review of environmental risk factors for orofacial clefts is provided by Rahimov et al. [2012] and Vieira [2012].

\section{Genetic Studies of NSCL/P}

The identification of genes contributing to NSCL/P has been the subject of decades of research, using a variety of approaches (e.g. linkage analysis, genomic rearrangements, candidate genes, genome-wide association studies) that, until recently, had only modest success [Dixon et al., 2011; Marazita 2012].

Linkage analysis-Linkage analysis studies are based on the co-segregation of genetic loci with disease and can be performed in large, multiplex families or in pairs of affected relatives. To date, 13 genome-wide linkage scans have been performed for NSCL/P. Although each study identified several positive signals, none had LOD scores reaching genome-wide significance [Marazita et al., 2004]. A large linkage study of 388 extended 
families from seven populations and meta-analysis combining six of the published linkage scans identified the first genome-wide significant linkage results on 1q32, 2p13, 3q27-28, 9q21, 14q21-24, and 16q24 [Marazita et al., 2004]. Subsequent fine-mapping of the 9q21 region identified FOXE1 as the causative gene at this locus [Letra et al., 2010; Marazita et al., 2009; Moreno et al., 2009].

Genomic Rearrangements and Copy Number Variants-Genomic rearrangements are caused by improper recombination of chromosomes and include deletions, duplications, translocations, and inversions that can occur within or between chromosomes. Analysis of breakpoints in patients with balanced rearrangements has identified CLPTM1 [Yoshiura et al., 1998], SATB2 [FitzPatrick et al., 2003], SUMO1 [Alkuraya et al., 2006], and FGFRI [Kim et al., 2005] as candidate genes for CL/P, and implicated $9 \mathrm{q}$ and $17 \mathrm{q}$ as potential risk loci [Machida et al., 2009]. In contrast, copy number variants (CNVs) and microdeletions are submicroscopic gains or losses of DNA segments ranging from kilobases to megabases. Although most CNVs have been found in syndromic forms of clefting, such as DiGeorge syndrome and VWS, recent studies have focused on the role of CNVs and microdeletions in nonsyndromic forms of clefting [Menezes et al., 2009; Osoegawa et al., 2008]. Genes implicated in NSCL/P from these approaches include FGFR2 [Osoegawa et al., 2008], TFAP2A [Shi et al., 2009], and SUMO1 [Shi et al., 2009].

Candidate Gene Approaches-In contrast to genome-wide approaches, such as linkage analysis, selection of candidate genes for study typically relies on a priori knowledge about the biological processes involved and can utilize a variety of sources, from animal models to Mendelian clefting syndromes. Mouse models with spontaneous clefts, those induced by chemical mutagenesis, or by knockout experiments have all been used for gene discovery. Expression analysis is another powerful tool for identifying and focusing lists of candidate genes. The Craniofacial and Oral Gene Expression Network database (COGENE, now available through the FaceBase online resource, www.FaceBase.org) catalogs gene expression patterns from early stage human embryos, while the EMAGE database catalogs extensive gene expression information for the developing mouse embryo [Armit et al., 2012].

Candidate genes can also be selected based on their role in syndromes that include clefting as part of the phenotype (see Table I). The rationale for this approach is that while rare, damaging mutations in a gene can cause a Mendelian clefting syndrome, the common, less deleterious variants of the same gene can contribute to a similarly less severe, isolated cleft [Stanier and Moore, 2004]. VWS is an excellent model for this as approximately $15 \%$ of VWS patients present as phenocopies of isolated, nonsyndromic clefts. While mutations in IRF6 are causative for VWS and PPS, variants in and around IRF6 have been associated with NSCL/P [Kondo et al., 2002; Rahimov et al., 2008; Zucchero et al., 2004].

Resequencing of candidate genes has successfully identified specific variants that may contribute to the statistical associations of several candidate genes including MSX1, FGFRl, FGF8, and BMP4 [Leslie and Murray 2012].

Genome Wide Association Studies-Genome wide association studies (GWAS) have become widely used for their unbiased approach for identifying candidate genes or loci associated with complex traits such as NSCL/P. To date, four independent GWAS and a meta-analysis have been published for NSCL/P [Beaty et al., 2010; Birnbaum et al., 2009; Grant et al., 2009; Ludwig et al., 2012; Mangold et al., 2010] (positive results summarized in Table II). Birnbaum et al. [2009] found an extremely strong association between markers on $8 \mathrm{q} 24$ and NSCL/P in a German population which was subsequently replicated in a population from the United States [Grant et al., 2009]. In the third study, Mangold et al. 
[2010] identified additional significant signals near VAX1 on chromosome 10q25 and NOG on chromosome 17q22. The fourth GWAS of NSCL/P was performed by the GENEVA Cleft Consortium study [Beaty et al., 2010]. Novel features of this study were the use of case-parent trios for the first time in a NSCL/P GWAS and the inclusion of a variety of families of European, Asian, and mixed ancestry. In the combined analysis for all populations, this study confirmed the previous associations with 1q32 and 8q24 and identified novel loci on $1 \mathrm{p} 22$ and 20q12. When stratified by population, markers near 1q32, $1 \mathrm{p} 22$ and 20q12 reached genome-wide significance in Asians, while only the 8q24 signal was formally significant in Europeans. An examination of marker information content and haplotype diversity for the 8q24 locus demonstrated low heterozygosity and low haplotype diversity in Asian populations [Murray et al., 2012]. The inclusion of additional SNPs by imputation revealed a strong, but not genome-wide significant, signal in Asian populations. Thus, the absence of a signal in Asian populations in the GWAS may not be due to a population effect, but lack of power due to low minor allele frequency.

To identify additional susceptibility loci, Ludwig et al. [2012] performed a meta-analysis by combining the GENEVA Cleft Consortium and Mangold et al. studies, which are the largest of the published GWAS. Combining the European case-control data with the EuropeanAmerican trios resulted in six loci reaching genome-wide significance $(8 \mathrm{q} 24,10 \mathrm{q} 25,17 \mathrm{q} 22$, $2 \mathrm{p} 21,13 \mathrm{q} 31$, and $15 \mathrm{q} 22$ ). The addition of the Asian trios from the GENEVA study resulted in smaller p-values for five of these loci (except 15q22), indicating that these loci contribute to NSCL/P in both European and Asian populations. In addition, six additional regions reached genome-wide significance (1p36, 1p22, 1q32, 3p11, 8q21, and 20q12). Mangold et al. also performed separate analyses for CL and CLP, demonstrating that the 13q31 locus was exclusively associated with CLP.

Unlike the multiple studies of NSCL/P, there are few genetic studies of nonsyndromic CP. SNPs from the four European NSCL/P GWAS loci (1q32, 8q24, 10q25, and 17q22) were tested in CP trios, but were not significant [Mangold et al., 2010]. A GWAS for CP was recently completed but lacked statistically significant SNP main effects. However, with the addition of environmental exposures, several significant gene-environment interaction effects emerged [Beaty et al., 2011]. There was little or no overlap between loci associated with NSCL/P and those associated with CP, suggesting that these clefting phenotypes have distinct etiologies and supporting the historical separation of NSCL/P from CP.

\section{Genes and Genetic Loci Best-supported as Involved in NSCL/P}

There are now multiple genes and genetic loci with support for involvement in NSCL/P from multiple lines of evidence. Many of these also have biological plausibility, as will now be reviewed.

IRF6: Interferon regulatory factor $6(I R F 6)$ was first implicated in orofacial clefting when it was discovered to be the cause for two autosomal-dominant clefting syndromes: VWS and PPS [Kondo et al., 2002]. 15\% of VWS patients lack lip pits, making them clinically indistinguishable from individuals with nonsyndromic clefts. This led to the hypothesis that hypomorphic alleles in IRF6 might contribute to the etiology of NSCL/P, which was confirmed in a large study [Zucchero et al., 2004] involving several populations and subsequently replicated in genome-wide linkage studies [Marazita et al., 2009; Marazita et al., 2004], GWAS [Beaty et al., 2010; Birnbaum et al., 2009; Grant et al., 2009] and numerous candidate gene studies [Ghassibe et al., 2005; Jugessur et al., 2008; Park et al., 2007]. A study later identified a common SNP in the MCS-9.7 regulatory element that is over transmitted in nonsyndromic CL [Rahimov et al., 2008]. The risk allele disrupts a highly conserved binding site for transcription factor AP- $2 a$, which is mutated in the 
autosomal dominant clefting syndrome branchio-oculo-facial syndrome, which includes pits of the upper lip among its phenotypic features [Milunsky et al., 2008].

MAFB: The $M A F B$ gene encodes a basic leucine zipper transcription factor that is involved in development and differentiation of keratinocytes [Borrelli et al., 2010] and at least in the mouse has been shown to be expressed in the PS and the medial edge epithelia (or MEE) during palatal fusion [Beaty et al., 2010]. Several markers on chromosome 20q12 near $M A F B$ achieved genome-wide significance in the GENEVA Cleft Consortium GWAS in European and Asian populations, although the signal was much stronger in Asians [Beaty et al., 2010]. Several independent studies using diverse populations have replicated this association [Beaty et al., 2010; Lennon et al., 2012; Pan et al., 2011]. Sequencing of the single $M A F B$ exon identified a missense mutation, H131Q (rs121912307), present in $3.5 \%$ of Filipinos with CL/P but only $0.7 \%$ of controls $(\mathrm{p}<0.0001)$. This variant is located in a poly-histidine tract, a motif that has been implicated in subcellular localization in other proteins. Although the function of this variant (and motif) is currently unknown, it is bioinformatically predicted to damage protein structure and/or function. Mutations in the transactivation domain cause multicentric carpotarsal osteolysis (MCTO), an autosomal dominant skeletal dysplasia characterized by progressive bone resorption [Dworschak et al., 2013; Zankl et al., 2012]. Individuals with MCTO can have craniofacial abnormalities such as triangular faces, micrognathia, and exophthalmos, but have not been reported to have CL/ P.

ARHGAP29: Multiple markers on chromosome 1p22, located in and around the $A B C A 4$ gene, which encodes an ATP-binding cassette transporter, reached genome-wide significance by GWAS [Beaty et al., 2010; Ludwig et al., 2012]. The most strongly associated SNPs were replicated in independent populations [Beaty et al., 2010; Lennon et al., 2012; Pan et al., 2011; Yildirim et al., 2012], which also showed a stronger signal in Asian families than in European ones. Mutations in $A B C A 4$ cause several autosomal recessive retinal diseases [Tsybovsky et al., 2010]. Despite identifying numerous missense mutations in this gene in individuals with NSCL/P, expression of mouse Abca4 was restricted to the retina at the RNA and protein level [Beaty et al., 2010]. Leslie et al., [2012a] demonstrated craniofacial expression of the adjacent gene Arhgap29, which was decreased in Irf6 knockout mice. Mutation screening of ARHGAP29 identified multiple rare coding variants in families with NSCL/P. ARHGAP29 encodes Rho GTPase activating protein 29, a protein that mediates the cyclical regulation of small GTP binding proteins (Saras et al., 1997) which are involved in many functions critical for craniofacial development related to cellular shape, movement, cell-cell interactions, and proliferation [Mossey et al., 2009].

8q24: $8 \mathrm{q} 24$ is a gene desert identified with striking significance in several complex diseases including NSCL/P [Beaty et al., 2010; Birnbaum et al., 2009; Grant et al., 2009; Mangold et al., 2010], prostate cancer [Haiman et al., 2007], colorectal cancer [Haerian et al., 2011; Zanke et al., 2007], bladder cancer [Kiemeney et al., 2008], and breast cancer [Easton et al., 2007]. The $8 \mathrm{q} 24$ region was strongly associated with NSCL/P in Caucasian populations and was independently identified by all GWAS. The closest gene to this locus is the oncogene $M Y C$, which directly interacts with at least one part of the 8q24 locus [Sotelo et al., 2010]. Myc is strongly expressed in the mandible and maxilla at E14.5 [Richardson et al., 2010] and is also required for neural crest cell formation [Bellmeyer et al., 2003; Wei et al., 2007]. Several regions demonstrating enhancer activity in craniofacial tissue have been identified at the 8q24 locus (www.facebase.org), leading to the hypothesis that this region contains multiple regulatory elements critical for proper craniofacial development. 
VAX1: $V A X 1$, ventral anterior homeobox 1, is a transcriptional regulator containing a DNAbinding homeobox domain. Markers in or near VAXI approached genome-wide significance in studies by Mangold et al. [2010] and the GENEVA Cleft Consortium [Beaty et al., 2010]; this association has been replicated in three independent Asian populations [Butali et al., 2013]. Resequencing of VAX1 failed to identify an excess of rare variants in NSCL/P [Nasser et al., 2012]. Vaxl is expressed in several craniofacial structures and mice deficient for Vaxl develop cleft palate [Hallonet, 1999]. Recently a homozygous missense mutation was described in a child from a consanguineous family with bilateral microphthalmia, bilateral CLP, and corpus callosum agenesis [Slavotinek et al., 2012], mimicking the phenotype of the $\operatorname{Vaxl}^{-/-}$mouse.

PAX7: Paired box protein Pax-7 (PAX7) is a transcription factor that in the mouse has been shown to have a role in neural crest development by regulating the expression of neural crest markers Slug, Sox9, and Sox10 [Basch et al., 2006]. Pax7 is expressed in the PS, Meckel's cartilage, and various nasal structures including the nasal epithelium. Mutant Pax7 mice have malformations of the maxilla and nose, confirming its role in craniofacial development [Mansouri et al., 1996]. In humans, several markers around $P A X 7$ approached genome-wide significance by GWAS [Beaty et al., 2010] and meta-analysis [Ludwig et al., 2012], suggesting a role for common variants of $P A X 7$ in the etiology of NSCL/P. Notably, PAX7 was previously associated with NSCL/P in four populations in a candidate gene association study [Sull et al., 2009].

\section{SUMMARY AND RECOMMENDATIONS}

Clefts of the lip and palate have been of interest in the scientific literature since at least the 1700 's, and currently represent one of the major success stories in applying modern molecular genetic techniques to a common, complex disorder. There have been major successes in sequencing Mendelian forms to identify causative variants (see Table I) and in performing genome-wide linkage and association approaches to identify genes and regions involved in NSCL/P (see Table II). Given the strong and consistent results obtained from GWAS, meta-analysis, and other genetic studies of NSCL/P, a number of research groups are now conducting sequencing studies to identify specific functional variants in the genes and regions identified, as well as their regulatory regions. Interestingly, with the exception of IRF6, genome-wide association studies versus genome-wide linkage approaches have identified non-overlapping regions implying that additional variation should be identifiable through sequencing and other approaches to detect rare variants.

Other research themes that are essential for future study include inclusion of phenotypic and ethnic diversity in studies, investigation of pathways and gene by gene interactions, identification of functional variants and understanding of their etiologic significance, and ultimately, translation of such results into the clinical management of cleft lip and cleft palate worldwide.

\section{Acknowledgments}

Many thanks to our many colleagues and mentors in the field of cleft lip/palate genetics. This review was partially supported by NIH grants T15-LM007059 (EJL), DE016148 and DE0200570 (MLM)

\section{References}

Abbott BD. The etiology of cleft palate: a 50-year search for mechanistic and molecular understanding. Birth Defects Res B Dev Reprod Toxicol. 2010; 89(4):266-274. [PubMed: 20602452] 
Alkuraya FS, Saadi I, Lund JJ, Turbe-Doan A, Morton CC, Maas RL. SUMO1 haploinsufficiency leads to cleft lip and palate. Science. 2006; 313(5794):1751. [PubMed: 16990542]

Armit C, Venkataraman S, Richardson L, Stevenson P, Moss J, Graham L, Ross A, Yang Y, Burton N, Rao J, Hill B, Rannie D, Wicks M, Davidson D, Baldock R. eMouseAtlas, EMAGE, and the spatial dimension of the transcriptome. Mamm Genome. 2012

Bamforth JS, Hughes IA, Lazarus JH, Weaver CM, Harper PS. Congenital hypothyroidism, spiky hair, and cleft palate. J Med Genet. 1989; 26(1):49-51. [PubMed: 2918525]

Basch ML, Bronner-Fraser M, Garcia-Castro MI. Specification of the neural crest occurs during gastrulation and requires Pax7. Nature. 2006; 441(7090):218-222. [PubMed: 16688176]

Beaty TH, Murray JC, Marazita ML, Munger RG, Ruczinski I, Hetmanski JB, Liang KY, Wu T, Murray T, Fallin MD, Redett RA, Raymond G, Schwender H, Jin SC, Cooper ME, Dunnwald M, Mansilla MA, Leslie E, Bullard S, Lidral AC, Moreno LM, Menezes R, Vieira AR, Petrin A, Wilcox AJ, Lie RT, Jabs EW, Wu-Chou YH, Chen PK, Wang H, Ye X, Huang S, Yeow V, Chong SS, Jee SH, Shi B, Christensen K, Melbye M, Doheny KF, Pugh EW, Ling H, Castilla EE, Czeizel AE, Ma L, Field LL, Brody L, Pangilinan F, Mills JL, Molloy AM, Kirke PN, Scott JM, ArcosBurgos M, Scott AF. A genome-wide association study of cleft lip with and without cleft palate identifies risk variants near MAFB and ABCA4. Nat Genet. 2010; 42(6):525-529. [PubMed: 20436469]

Beaty TH, Ruczinski I, Murray JC, Marazita ML, Munger RG, Hetmanski JB, Murray T, Redett RJ, Fallin MD, Liang KY, Wu T, Patel PJ, Jin SC, Zhang TX, Schwender H, Wu-Chou YH, Chen PK, Chong SS, Cheah F, Yeow V, Ye X, Wang H, Huang S, Jabs EW, Shi B, Wilcox AJ, Lie RT, Jee SH, Christensen K, Doheny KF, Pugh EW, Ling H, Scott AF. Evidence for gene-environment interaction in a genome wide study of nonsyndromic cleft palate. Genet Epidemiol. 2011; 35(6): 469-478. [PubMed: 21618603]

Bellmeyer A, Krase J, Lindgren J, LaBonne C. The protooncogene c-myc is an essential regulator of neural crest formation in xenopus. Dev Cell. 2003; 4(6):827-839. [PubMed: 12791268]

Benko S, Fantes JA, Amiel J, Kleinjan DJ, Thomas S, Ramsay J, Jamshidi N, Essafi A, Heaney S, Gordon CT, McBride D, Golzio C, Fisher M, Perry P, Abadie V, Ayuso C, Holder-Espinasse M, Kilpatrick N, Lees MM, Picard A, Temple IK, Thomas P, Vazquez MP, Vekemans M, Roest Crollius H, Hastie ND, Munnich A, Etchevers HC, Pelet A, Farlie PG, Fitzpatrick DR, Lyonnet S. Highly conserved non-coding elements on either side of SOX9 associated with Pierre Robin sequence. Nat Genet. 2009; 41(3):359-364. [PubMed: 19234473]

Berk, NW.; Marazita, ML. The Costs of Cleft Lip and Palate: Personal and Societal Implications. In: Wyszynski, DF., editor. Cleft Lip and Palate: From Origin to Treatment. Oxford: Oxford University Press; 2002.

Bille C, Knudsen LB, Christensen K. Changing lifestyles and oral clefts occurrence in Denmark. Cleft Palate Craniofacial Journal. 2005; 42(3):255-259. [PubMed: 15865458]

Birnbaum S, Ludwig KU, Reutter H, Herms S, Steffens M, Rubini M, Baluardo C, Ferrian M, Almeida de Assis N, Alblas MA, Barth S, Freudenberg J, Lauster C, Schmidt G, Scheer M, Braumann B, Berge SJ, Reich RH, Schiefke F, Hemprich A, Potzsch S, Steegers-Theunissen RP, Potzsch B, Moebus S, Horsthemke B, Kramer FJ, Wienker TF, Mossey PA, Propping P, Cichon S, Hoffmann P, Knapp M, Nothen MM, Mangold E. Key susceptibility locus for nonsyndromic cleft lip with or without cleft palate on chromosome 8q24. Nat Genet. 2009; 41(4):473-477. [PubMed: 19270707]

Borrelli S, Fanoni D, Dolfini D, Alotto D, Ravo M, Grober OM, Weisz A, Castagnoli C, Berti E, Vigano MA, Mantovani R. C/EBPdelta gene targets in human keratinocytes. PLoS ONE. 2010; 5(11):e13789. [PubMed: 21072181]

Boyles AL, DeRoo LA, Lie RT, Taylor JA, Jugessur A, Murray JC, Wilcox AJ. Maternal alcohol consumption, alcohol metabolism genes, and the risk of oral clefts: a population-based casecontrol study in Norway, 1996-2001. Am J Epidemiol. 2010; 172(8):924-931. [PubMed: 20810466]

Braybrook C, Doudney K, Marcano AC, Arnason A, Bjornsson A, Patton MA, Goodfellow PJ, Moore GE, Stanier P. The T-box transcription factor gene TBX22 is mutated in X-linked cleft palate and ankyloglossia. Nat Genet. 2001; 29(2):179-183. [PubMed: 11559848]

Burdick AB. Genetic epidemiology and control of genetic expression in van der Woude syndrome. $\mathrm{J}$ Craniofac Genet Dev Biol Suppl. 1986; 2:99-105. [PubMed: 3491128] 
Butali A, Suzuki S, Cooper ME, Mansilla AM, Cuenco K, Leslie EJ, Suzuki Y, Niimi T, Yamamoto M, Ayanga G, Erkhembaatar T, Furukawa H, Fujiwawa K, Imura H, Petrin AL, Natsume N, Beaty TH, Marazita ML, Murray JC. Replication of Genome Wide Association Identified Candidate Genes Confirm the Role of Common and Rare Variants in PAX7 and VAX1 in the Etiology of Nonsyndromic CL(P). Am J Med Genet A. 2013; 161(5):965-972. [PubMed: 23463464]

Carmichael SL, Nelson V, Shaw GM, Wasserman CR, Croen LA. Socio-economic status and risk of conotruncal heart defects and orofacial clefts. Paediatr Perinat Epidemiol. 2003; 17(3):264-271. [PubMed: 12839538]

Celli J, Duijf P, Hamel BC, Bamshad M, Kramer B, Smits AP, Newbury-Ecob R, Hennekam RC, Van Buggenhout G, van Haeringen A, Woods CG, van Essen AJ, de Waal R, Vriend G, Haber DA, Yang A, McKeon F, Brunner HG, van Bokhoven H. Heterozygous germline mutations in the p53 homolog p63 are the cause of EEC syndrome. Cell. 1999; 99(2):143-153. [PubMed: 10535733]

Christensen K, Juel K, Herskind AM, Murray JC. Long term follow up study of survival associated with cleft lip and palate at birth. BMJ. 2004; 328(7453):1405. [PubMed: 15145797]

Clark JD, Mossey PA, Sharp L, Little J. Socioeconomic status and orofacial clefts in Scotland, 1989 to 1998. Cleft Palate Craniofac J. 2003; 40(5):481-485. [PubMed: 12943441]

Darwin, C. The variation of animals and plants under domestication. London, England: John Murray, Albermarle Street; 1875.

de Lima RL, Hoper SA, Ghassibe M, Cooper ME, Rorick NK, Kondo S, Katz L, Marazita ML, Compton J, Bale S, Hehr U, Dixon MJ, Daack-Hirsch S, Boute O, Bayet B, Revencu N, VerellenDumoulin C, Vikkula M, Richieri-Costa A, Moretti-Ferreira D, Murray JC, Schutte BC. Prevalence and nonrandom distribution of exonic mutations in interferon regulatory factor 6 in 307 families with Van der Woude syndrome and 37 families with popliteal pterygium syndrome. Genet Med. 2009; 11(4):241-247. [PubMed: 19282774]

Dietz A, Pedersen DA, Jacobsen R, Wehby GL, Murray JC, Christensen K. Risk of breast cancer in families with cleft lip and palate. Ann Epidemiol. 2012; 22(1):37-42. [PubMed: 22037380]

Dixon MJ, Marazita ML, Beaty TH, Murray JC. Cleft lip and palate: understanding genetic and environmental influences. Nat Rev Genet. 2011; 12(3):167-178. [PubMed: 21331089]

Dode C, Levilliers J, Dupont JM, De Paepe A, Le Du N, Soussi-Yanicostas N, Coimbra RS, Delmaghani S, Compain-Nouaille S, Baverel F, Pecheux C, Le Tessier D, Cruaud C, Delpech M, Speleman F, Vermeulen S, Amalfitano A, Bachelot Y, Bouchard P, Cabrol S, Carel JC, Delemarre-van de Waal H, Goulet-Salmon B, Kottler ML, Richard O, Sanchez-Franco F, Saura R, Young J, Petit C, Hardelin JP. Loss-of-function mutations in FGFR1 cause autosomal dominant Kallmann syndrome. Nat Genet. 2003; 33(4):463-465. [PubMed: 12627230]

Dworschak GC, Draaken M, Hilger A, Born M, Reutter H, Ludwig M. An incompletely penetrant novel MAFB (p.Ser56Phe) variant in autosomal dominant multicentric carpotarsal osteolysis syndrome. Int J Mol Med. 2013; 32(1):174-178. [PubMed: 23670161]

Easton DF, Pooley KA, Dunning AM, Pharoah PD, Thompson D, Ballinger DG, Struewing JP, Morrison J, Field H, Luben R, Wareham N, Ahmed S, Healey CS, Bowman R, Meyer KB, Haiman CA, Kolonel LK, Henderson BE, Le Marchand L, Brennan P, Sangrajrang S, Gaborieau V, Odefrey F, Shen CY, Wu PE, Wang HC, Eccles D, Evans DG, Peto J, Fletcher O, Johnson N, Seal S, Stratton MR, Rahman N, Chenevix-Trench G, Bojesen SE, Nordestgaard BG, Axelsson CK, Garcia-Closas M, Brinton L, Chanock S, Lissowska J, Peplonska B, Nevanlinna H, Fagerholm R, Eerola H, Kang D, Yoo KY, Noh DY, Ahn SH, Hunter DJ, Hankinson SE, Cox DG, Hall P, Wedren S, Liu J, Low YL, Bogdanova N, Schurmann P, Dork T, Tollenaar RA, Jacobi CE, Devilee P, Klijn JG, Sigurdson AJ, Doody MM, Alexander BH, Zhang J, Cox A, Brock IW, MacPherson G, Reed MW, Couch FJ, Goode EL, Olson JE, Meijers-Heijboer H, van den Ouweland A, Uitterlinden A, Rivadeneira F, Milne RL, Ribas G, Gonzalez-Neira A, Benitez J, Hopper JL, McCredie M, Southey M, Giles GG, Schroen C, Justenhoven C, Brauch H, Hamann U, Ko YD, Spurdle AB, Beesley J, Chen X, Mannermaa A, Kosma VM, Kataja V, Hartikainen J, Day NE, Cox DR, Ponder BA. Genome-wide association study identifies novel breast cancer susceptibility loci. Nature. 2007; 447(7148):1087-1093. [PubMed: 17529967]

el Ghouzzi V, Le Merrer M, Perrin-Schmitt F, Lajeunie E, Benit P, Renier D, Bourgeois P, BolcatoBellemin AL, Munnich A, Bonaventure J. Mutations of the TWIST gene in the Saethre-Chotzen syndrome. Nat Genet. 1997; 15(1):42-46. [PubMed: 8988167] 
Ferrante MI, Giorgio G, Feather SA, Bulfone A, Wright V, Ghiani M, Selicorni A, Gammaro L, Scolari F, Woolf AS, Sylvie O, Bernard L, Malcolm S, Winter R, Ballabio A, Franco B. Identification of the gene for oral-facial-digital type I syndrome. Am J Hum Genet. 2001; 68(3): 569-576. [PubMed: 11179005]

FitzPatrick DR, Carr IM, McLaren L, Leek JP, Wightman P, Williamson K, Gautier P, McGill N, Hayward C, Firth H, Markham AF, Fantes JA, Bonthron DT. Identification of SATB2 as the cleft palate gene on 2q32-q33. Hum Mol Genet. 2003; 12(19):2491-2501. [PubMed: 12915443]

Fogh-Andersen, P. Inheritance of Harelip and Cleft Palate. Copenhagen: Munksgaard; 1942.

Foster JW, Dominguez-Steglich MA, Guioli S, Kwok C, Weller PA, Stevanovic M, Weissenbach J, Mansour S, Young ID, Goodfellow PN, et al. Campomelic dysplasia and autosomal sex reversal caused by mutations in an SRY-related gene. Nature. 1994; 372(6506):525-530. [PubMed: 7990924]

Fraser FC. Thoughts on the etiology of clefts of the palate and lip. Acta Genet Stat Med. 1955; 5(4): 358-369. [PubMed: 13339079]

Frebourg T, Oliveira C, Hochain P, Karam R, Manouvrier S, Graziadio C, Vekemans M, Hartmann A, Baert-Desurmont S, Alexandre C, Lejeune Dumoulin S, Marroni C, Martin C, Castedo S, Lovett M, Winston J, Machado JC, Attie T, Jabs EW, Cai J, Pellerin P, Triboulet JP, Scotte M, Le Pessot F, Hedouin A, Carneiro F, Blayau M, Seruca R. Cleft lip/palate and CDH1/E-cadherin mutations in families with hereditary diffuse gastric cancer. J Med Genet. 2006; 43(2):138-142. [PubMed: 15831593]

Ghassibe M, Bayet B, Revencu N, Verellen-Dumoulin C, Gillerot Y, Vanwijck R, Vikkula M. Interferon regulatory factor-6: a gene predisposing to isolated cleft lip with or without cleft palate in the Belgian population. Eur J Hum Genet. 2005; 13(11):1239-1242. [PubMed: 16132054]

Grant SF, Wang K, Zhang H, Glaberson W, Annaiah K, Kim CE, Bradfield JP, Glessner JT, Thomas KA, Garris M, Frackelton EC, Otieno FG, Chiavacci RM, Nah HD, Kirschner RE, Hakonarson H. A genome-wide association study identifies a locus for nonsyndromic cleft lip with or without cleft palate on 8q24. J Pediatr. 2009; 155(6):909-913. [PubMed: 19656524]

Gripp KW, Wotton D, Edwards MC, Roessler E, Ades L, Meinecke P, Richieri-Costa A, Zackai EH, Massague J, Muenke M, Elledge SJ. Mutations in TGIF cause holoprosencephaly and link NODAL signalling to human neural axis determination. Nat Genet. 2000; 25(2):205-208. [PubMed: 10835638]

Gritli-Linde A. Molecular control of secondary palate development. Dev Biol. 2007; 301(2):309-326. [PubMed: 16942766]

Grosen D, Bille C, Petersen I, Skytthe A, Hjelmborg J, Pedersen JK, Murray JC, Christensen K. Risk of oral clefts in twins. Epidemiology. 2011; 22(3):313-319. [PubMed: 21423016]

Grosen D, Chevrier C, Skytthe A, Bille C, Molsted K, Sivertsen A, Murray JC, Christensen K. A cohort study of recurrence patterns among more than 54,000 relatives of oral cleft cases in Denmark: support for the multifactorial threshold model of inheritance. J Med Genet. 2010; 47(3): 162-168. [PubMed: 19752161]

Group TCC. Positional cloning of a gene involved in the pathogenesis of Treacher Collins syndrome. The Treacher Collins Syndrome Collaborative Group. Nat Genet. 1996; 12(2):130-136. [PubMed: 8563749]

Gundlach KK, Maus C. Epidemiological studies on the frequency of clefts in Europe and world-wide. J Craniomaxillofac Surg. 2006; 34(Suppl 2):1-2. [PubMed: 17071381]

Haerian MS, Baum L, Haerian BS. Association of 8q24.21 loci with the risk of colorectal cancer: a systematic review and meta-analysis. J Gastroenterol Hepatol. 2011; 26(10):1475-1484. [PubMed: 21722176]

Hahn H, Wicking C, Zaphiropoulous PG, Gailani MR, Shanley S, Chidambaram A, Vorechovsky I, Holmberg E, Unden AB, Gillies S, Negus K, Smyth I, Pressman C, Leffell DJ, Gerrard B, Goldstein AM, Dean M, Toftgard R, Chenevix-Trench G, Wainwright B, Bale AE. Mutations of the human homolog of Drosophila patched in the nevoid basal cell carcinoma syndrome. Cell. 1996; 85(6):841-851. [PubMed: 8681379]

Haiman CA, Patterson N, Freedman ML, Myers SR, Pike MC, Waliszewska A, Neubauer J, Tandon A, Schirmer C, McDonald GJ, Greenway SC, Stram DO, Le Marchand L, Kolonel LN, Frasco M, 
Wong D, Pooler LC, Ardlie K, Oakley-Girvan I, Whittemore AS, Cooney KA, John EM, Ingles SA, Altshuler D, Henderson BE, Reich D. Multiple regions within 8q24 independently affect risk for prostate cancer. Nat Genet. 2007; 39(5):638-644. [PubMed: 17401364]

Hallonet M, Hollemann T, Pieler T, Gruss P. Vax1, a novel homeobox-containing gene, directs development of the basal forebrain and visual system. Genes Development. 1999; 13(23):31063114. [PubMed: 10601036]

Howard TD, Paznekas WA, Green ED, Chiang LC, Ma N, Ortiz de Luna RI, Garcia Delgado C, Gonzalez-Ramos M, Kline AD, Jabs EW. Mutations in TWIST, a basic helix-loop-helix transcription factor, in Saethre-Chotzen syndrome. Nat Genet. 1997; 15(1):36-41. [PubMed: 8988166]

Jensen BL, Kreiborg S, Dahl E, Fogh-Andersen P. Cleft lip and palate in Denmark, 1976-1981: epidemiology, variability, and early somatic development. Cleft Palate J. 1988; 25(3):258-269. [PubMed: 3262457]

Jiang R, Bush JO, Lidral AC. Development of the upper lip: morphogenetic and molecular mechanisms. Dev Dyn. 2006; 235(5):1152-1166. [PubMed: 16292776]

Johnson CY, Little J. Folate intake, markers of folate status and oral clefts: is the evidence converging? Int J Epidemiol. 2008; 37(5):1041-1058. [PubMed: 18583393]

Johnson RL, Rothman AL, Xie J, Goodrich LV, Bare JW, Bonifas JM, Quinn AG, Myers RM, Cox DR, Epstein EH Jr, Scott MP. Human homolog of patched, a candidate gene for the basal cell nevus syndrome. Science. 1996; 272(5268):1668-1671. [PubMed: 8658145]

Johnston JJ, Sapp JC, Turner JT, Amor D, Aftimos S, Aleck KA, Bocian M, Bodurtha JN, Cox GF, Curry CJ, Day R, Donnai D, Field M, Fujiwara I, Gabbett M, Gal M, Graham JM, Hedera P, Hennekam RC, Hersh JH, Hopkin RJ, Kayserili H, Kidd AM, Kimonis V, Lin AE, Lynch SA, Maisenbacher M, Mansour S, McGaughran J, Mehta L, Murphy H, Raygada M, Robin NH, Rope AF, Rosenbaum KN, Schaefer GB, Shealy A, Smith W, Soller M, Sommer A, Stalker HJ, Steiner B, Stephan MJ, Tilstra D, Tomkins S, Trapane P, Tsai AC, Van Allen MI, Vasudevan PC, Zabel B, Zunich J, Black GC, Biesecker LG. Molecular analysis expands the spectrum of phenotypes associated with GLI3 mutations. Hum Mutat. 2010; 31(10):1142-1154. [PubMed: 20672375]

Jugessur A, Farlie PG, Kilpatrick N. The genetics of isolated orofacial clefts: from genotypes to subphenotypes. Oral Dis. 2009a; 15(7):437-453. [PubMed: 19583827]

Jugessur A, Rahimov F, Lie RT, Wilcox AJ, Gjessing HK, Nilsen RM, Nguyen TT, Murray JC. Genetic variants in IRF6 and the risk of facial clefts: single-marker and haplotype-based analyses in a population-based case-control study of facial clefts in Norway. Genet Epidemiol. 2008; 32(5): 413-424. [PubMed: 18278815]

Jugessur A, Shi M, Gjessing HK, Lie RT, Wilcox AJ, Weinberg CR, Christensen K, Boyles AL, Daack-Hirsch S, Trung TN, Bille C, Lidral AC, Murray JC. Genetic determinants of facial clefting: analysis of 357 candidate genes using two national cleft studies from Scandinavia. PLoS ONE. 2009b; 4(4):e5385. [PubMed: 19401770]

Kalay E, Sezgin O, Chellappa V, Mutlu M, Morsy H, Kayserili H, Kreiger E, Cansu A, Toraman B, Abdalla EM, Aslan Y, Pillai S, Akarsu NA. Mutations in RIPK4 cause the autosomal-recessive form of popliteal pterygium syndrome. Am J Hum Genet. 2012; 90(1):76-85. [PubMed: 22197489]

Kiemeney LA, Thorlacius S, Sulem P, Geller F, Aben KK, Stacey SN, Gudmundsson J, Jakobsdottir M, Bergthorsson JT, Sigurdsson A, Blondal T, Witjes JA, Vermeulen SH, Hulsbergen-van de Kaa CA, Swinkels DW, Ploeg M, Cornel EB, Vergunst H, Thorgeirsson TE, Gudbjartsson D, Gudjonsson SA, Thorleifsson G, Kristinsson KT, Mouy M, Snorradottir S, Placidi D, Campagna M, Arici C, Koppova K, Gurzau E, Rudnai P, Kellen E, Polidoro S, Guarrera S, Sacerdote C, Sanchez M, Saez B, Valdivia G, Ryk C, de Verdier P, Lindblom A, Golka K, Bishop DT, Knowles MA, Nikulasson S, Petursdottir V, Jonsson E, Geirsson G, Kristjansson B, Mayordomo JI, Steineck G, Porru S, Buntinx F, Zeegers MP, Fletcher T, Kumar R, Matullo G, Vineis P, Kiltie AE, Gulcher JR, Thorsteinsdottir U, Kong A, Rafnar T, Stefansson K. Sequence variant on 8q24 confers susceptibility to urinary bladder cancer. Nat Genet. 2008; 40(11):1307-1312. [PubMed: 18794855]

Kim HG, Herrick SR, Lemyre E, Kishikawa S, Salisz JA, Seminara S, MacDonald ME, Bruns GA, Morton CC, Quade BJ, Gusella JF. Hypogonadotropic hypogonadism and cleft lip and palate 
caused by a balanced translocation producing haploinsufficiency for FGFR1. J Med Genet. 2005; 42(8):666-672. [PubMed: 16061567]

Kondo S, Schutte BC, Richardson RJ, Bjork BC, Knight AS, Watanabe Y, Howard E, de Lima RL, Daack-Hirsch S, Sander A, McDonald-McGinn DM, Zackai EH, Lammer EJ, Aylsworth AS, Ardinger HH, Lidral AC, Pober BR, Moreno L, Arcos-Burgos M, Valencia C, Houdayer C, Bahuau M, Moretti-Ferreira D, Richieri-Costa A, Dixon MJ, Murray JC. Mutations in IRF6 cause Van der Woude and popliteal pterygium syndromes. Nat Genet. 2002; 32(2):285-289. [PubMed: 12219090]

Krantz ID, McCallum J, DeScipio C, Kaur M, Gillis LA, Yaeger D, Jukofsky L, Wasserman N, Bottani A, Morris CA, Nowaczyk MJ, Toriello H, Bamshad MJ, Carey JC, Rappaport E, Kawauchi S, Lander AD, Calof AL, Li HH, Devoto M, Jackson LG. Cornelia de Lange syndrome is caused by mutations in NIPBL, the human homolog of Drosophila melanogaster Nipped-B. Nat Genet. 2004; 36(6):631-635. [PubMed: 15146186]

Laumonnier F, Holbert S, Ronce N, Faravelli F, Lenzner S, Schwartz CE, Lespinasse J, Van Esch H, Lacombe D, Goizet C, Phan-Dinh Tuy F, van Bokhoven H, Fryns JP, Chelly J, Ropers HH, Moraine C, Hamel BC, Briault S. Mutations in PHF8 are associated with X linked mental retardation and cleft lip/cleft palate. J Med Genet. 2005; 42(10):780-786. [PubMed: 16199551]

Lederer D, Grisart B, Digilio MC, Benoit V, Crespin M, Ghariani SC, Maystadt I, Dallapiccola B, Verellen-Dumoulin C. Deletion of KDM6A, a histone demethylase interacting with MLL2, in three patients with Kabuki syndrome. Am J Hum Genet. 2012; 90(1):119-124. [PubMed: 22197486]

Lennon, CJ.; Birkeland, AC.; Nunez, JA.; Su, GH.; Lanzano, P.; Guzman, E.; Celis, K.; Eisig, SB.; Hoffman, D.; Rendon, MT.; Ostos, H.; Chung, WK.; Haddad, J, Jr. Laryngoscope. 2012. Association of candidate genes with nonsyndromic clefts in Honduran and Colombian populations.

Leslie EJ, Mansilla MA, Biggs LC, Schuette K, Bullard S, Cooper M, Dunnwald M, Lidral AC, Marazita ML, Beaty TH, Murray JC. Expression and mutation analyses implicate ARHGAP29 as the etiologic gene for the cleft lip with or without cleft palate locus identified by genome-wide association on chromosome 1p22. Birth Defects Research Part A: Clinical and Molecular Teratology. 2012a:n/a-n/a.

Leslie EJ, Murray JC. Evaluating rare coding variants as contributing causes to nonsyndromic cleft lip and palate. Clin Genet. 2012:n/a-n/a.

Leslie EJ, Standley J, Compton J, Bale S, Schutte BC, Murray JC. Comparative analysis of IRF6 variants in families with Van der Woude syndrome and popliteal pterygium syndrome using public whole-exome databases. Genet Med. 2012b

Letra A, Menezes R, Govil M, Fonseca RF, McHenry T, Granjeiro JM, Castilla EE, Orioli IM, Marazita ML, Vieira AR. Follow-up association studies of chromosome region 9q and nonsyndromic cleft lip/palate. Am J Med Genet A. 2010; 152A(7):1701-1710. [PubMed: 20583170]

Little J, Bryan E. Congenital anomalies in twins. Semin Perinatol. 1986; 10(1):50-64. [PubMed: 3532342]

Loeys BL, Chen J, Neptune ER, Judge DP, Podowski M, Holm T, Meyers J, Leitch CC, Katsanis N, Sharifi N, Xu FL, Myers LA, Spevak PJ, Cameron DE, De Backer J, Hellemans J, Chen Y, Davis EC, Webb CL, Kress W, Coucke P, Rifkin DB, De Paepe AM, Dietz HC. A syndrome of altered cardiovascular, craniofacial, neurocognitive and skeletal development caused by mutations in TGFBR1 or TGFBR2. Nat Genet. 2005; 37(3):275-281. [PubMed: 15731757]

Ludwig KU, Mangold E, Herms S, Nowak S, Reutter H, Paul A, Becker J, Herberz R, Alchawa T, Nasser E, Bohmer AC, Mattheisen M, Alblas MA, Barth S, Kluck N, Lauster C, Braumann B, Reich RH, Hemprich A, Potzsch S, Blaumeiser B, Daratsianos N, Kreusch T, Murray JC, Marazita ML, Ruczinski I, Scott AF, Beaty TH, Kramer FJ, Wienker TF, Steegers-Theunissen RP, Rubini M, Mossey PA, Hoffmann P, Lange C, Cichon S, Propping P, Knapp M, Nothen MM. Genomewide meta-analyses of nonsyndromic cleft lip with or without cleft palate identify six new risk loci. Nat Genet. 2012

Machida J, Felix TM, Murray JC, Yoshiura K, Tanemura M, Kamamoto M, Shimozato K, Sonta S, Ono T. Searching for genes for cleft lip and/or palate based on breakpoint analysis of a balanced 
translocation t(9;17)(q32;q12). Cleft Palate Craniofacial Journal. 2009; 46(5):532-540. [PubMed: 19929093]

Mangold E, Ludwig KU, Birnbaum S, Baluardo C, Ferrian M, Herms S, Reutter H, de Assis NA, Chawa TA, Mattheisen M, Steffens M, Barth S, Kluck N, Paul A, Becker J, Lauster C, Schmidt G, Braumann B, Scheer M, Reich RH, Hemprich A, Potzsch S, Blaumeiser B, Moebus S, Krawczak M, Schreiber S, Meitinger T, Wichmann HE, Steegers-Theunissen RP, Kramer FJ, Cichon S, Propping P, Wienker TF, Knapp M, Rubini M, Mossey PA, Hoffmann P, Nothen MM. Genomewide association study identifies two susceptibility loci for nonsyndromic cleft lip with or without cleft palate. Nat Genet. 2010; 42(1):24-26. [PubMed: 20023658]

Mansouri A, Stoykova A, Torres M, Gruss P. Dysgenesis of cephalic neural crest derivatives in Pax7-/ - mutant mice. Development. 1996; 122(3):831-838. [PubMed: 8631261]

Marazita ML. The Evolution of Human Genetic Studies of Cleft Lip and Cleft Palate. Annu Rev Genomics Hum Genet. 2012

Marazita ML, Lidral AC, Murray JC, Field LL, Maher BS, Goldstein McHenry T, Cooper ME, Govil M, Daack-Hirsch S, Riley B, Jugessur A, Felix T, Morene L, Mansilla MA, Vieira AR, Doheny K, Pugh E, Valencia-Ramirez C, Arcos-Burgos M. Genome scan, fine-mapping, and candidate gene analysis of non-syndromic cleft lip with or without cleft palate reveals phenotype-specific differences in linkage and association results. Hum Hered. 2009; 68(3):151-170. [PubMed: 19521098]

Marazita ML, Murray JC, Lidral AC, Arcos-Burgos M, Cooper ME, Goldstein T, Maher BS, DaackHirsch S, Schultz R, Mansilla MA, Field LL, Liu YE, Prescott N, Malcolm S, Winter R, Ray A, Moreno L, Valencia C, Neiswanger K, Wyszynski DF, Bailey-Wilson JE, Albacha-Hejazi H, Beaty TH, McIntosh I, Hetmanski JB, Tuncbilek G, Edwards M, Harkin L, Scott R, Roddick LG. Meta-analysis of 13 genome scans reveals multiple cleft lip/palate genes with novel loci on 9q21 and 2q32-35. Am J Hum Genet. 2004; 75(2):161-173. [PubMed: 15185170]

Marazita ML, Spence MA, Melnick M. Genetic analysis of cleft lip with or without cleft palate in Danish kindreds. Am J Med Genet. 1984; 19(1):9-18. [PubMed: 6496575]

McGrath JA, Duijf PH, Doetsch V, Irvine AD, de Waal R, Vanmolkot KR, Wessagowit V, Kelly A, Atherton DJ, Griffiths WA, Orlow SJ, van Haeringen A, Ausems MG, Yang A, McKeon F, Bamshad MA, Brunner HG, Hamel BC, van Bokhoven H. Hay-Wells syndrome is caused by heterozygous missense mutations in the SAM domain of p63. Hum Mol Genet. 2001; 10(3):221229. [PubMed: 11159940]

Menezes R, Marazita ML, Goldstein McHenry T, Cooper ME, Bardi K, Brandon C, Letra A, Martin RA, Vieira AR. AXIS inhibition protein 2, orofacial clefts and a family history of cancer. J Am Dent Assoc. 2009; 140(1):80-84. [PubMed: 19119171]

Milunsky JM, Maher TA, Zhao G, Roberts AE, Stalker HJ, Zori RT, Burch MN, Clemens M, Mulliken JB, Smith R, Lin AE. TFAP2A mutations result in branchio-oculo-facial syndrome. Am J Hum Genet. 2008; 82(5):1171-1177. [PubMed: 18423521]

Mitchell K, O’Sullivan J, Missero C, Blair E, Richardson R, Anderson B, Antonini D, Murray JC, Shanske AL, Schutte BC, Romano RA, Sinha S, Bhaskar SS, Black GC, Dixon J, Dixon MJ. Exome sequence identifies RIPK4 as the Bartsocas-Papas syndrome locus. Am J Hum Genet. 2012; 90(1):69-75. [PubMed: 22197488]

Mitchell, LE. Mode of inheritance of oral clefts. In: Wyszyski, DF., editor. Cleft Lip and Palate: From Origin to Treatment. Oxford University Press; 2002. p. 234-239.

Moreno LM, Mansilla MA, Bullard SA, Cooper ME, Busch TD, Machida J, Johnson MK, Brauer D, Krahn K, Daack-Hirsch S, L'Heureux J, Valencia-Ramirez C, Rivera D, Lopez AM, Moreno MA, Hing A, Lammer EJ, Jones M, Christensen K, Lie RT, Jugessur A, Wilcox AJ, Chines P, Pugh E, Doheny K, Arcos-Burgos M, Marazita ML, Murray JC, Lidral AC. FOXE1 association with both isolated cleft lip with or without cleft palate, and isolated cleft palate. Hum Mol Genet. 2009; 18(24):4879-4896. [PubMed: 19779022]

Morgan NV, Brueton LA, Cox P, Greally MT, Tolmie J, Pasha S, Aligianis IA, van Bokhoven H, Marton T, Al-Gazali L, Morton JE, Oley C, Johnson CA, Trembath RC, Brunner HG, Maher ER. Mutations in the embryonal subunit of the acetylcholine receptor (CHRNG) cause lethal and Escobar variants of multiple pterygium syndrome. Am J Hum Genet. 2006; 79(2):390-395. [PubMed: 16826531] 
Mossey PA, Little J, Munger RG, Dixon MJ, Shaw WC. Cleft lip and palate. Lancet. 2009; 374(9703): 1773-1785. [PubMed: 19747722]

Munger RG, Tamura T, Johnston KE, Feldkamp ML, Pfister R, Carey JC. Plasma zinc concentrations of mothers and the risk of oral clefts in their children in Utah. Birth Defects Research Part A Clinical and Molecular Teratology. 2009; 85(2):151-155.

Murray JC. Gene/environment causes of cleft lip and/or palate. Clin Genet. 2002; 61(4):248-256. [PubMed: 12030886]

Murray T, Taub MA, Ruczinski I, Scott AF, Hetmanski JB, Schwender H, Patel P, Zhang TX, Munger RG, Wilcox AJ, Ye X, Wang H, Wu T, Wu-Chou YH, Shi B, Jee SH, Chong S, Yeow V, Murray JC, Marazita ML, Beaty TH. Examining markers in 8q24 to explain differences in evidence for association with cleft lip with/without cleft palate between Asians and Europeans. Genet Epidemiol. 2012; 36(4):392-399. [PubMed: 22508319]

Nasser E, Mangold E, Tradowsky DC, Fier H, Becker J, Boehmer AC, Herberz R, Fricker N, Barth S, Wahle P, Nowak S, Reutter H, Reich RH, Lauster C, Braumann B, Kreusch T, Hemprich A, Potzsch B, Hoffmann P, Kramer FJ, Knapp M, Lange C, Nothen MM, Ludwig KU. Resequencing of VAX1 in patients with nonsyndromic cleft lip with or without cleft palate. Birt Defects Res A Clin Mol Teratol. 2012; 94(11):925-933.

Neiswanger K, Chirigos KW, Klotz CM, Cooper ME, Bardi KM, Brandon CA, Weinberg SM, Vieira AR, Martin RA, Czeizel AE, Castilla EE, Poletta FA, Marazita ML. Whorl patterns on the lower lip are associated with nonsyndromic cleft lip with or without cleft palate. Am J Med Genet A. 2009; 149A(12):2673-2679. [PubMed: 19921634]

Neiswanger K, Weinberg SM, Rogers CR, Brandon CA, Cooper ME, Bardi KM, Deleyiannis FWB, Resick JR, Bowen A, Mooney MP, de Salamanca JE, Gonzalez B, Maher BS, Martin RA, Marazita ML. Orbicularis Oris Muscle Defects as an Expanded Phenotypic Feature in Nonsyndromic Cleft Lip with or without Cleft Palate. Am J Med Genet. 2007; 143A(11):11431149. [PubMed: 17497721]

Ng D, Thakker N, Corcoran CM, Donnai D, Perveen R, Schneider A, Hadley DW, Tifft C, Zhang L, Wilkie AO, van der Smagt JJ, Gorlin RJ, Burgess SM, Bardwell VJ, Black GC, Biesecker LG. Oculofaciocardiodental and Lenz microphthalmia syndromes result from distinct classes of mutations in BCOR. Nat Genet. 2004; 36(4):411-416. [PubMed: 15004558]

Ng SB, Bigham AW, Buckingham KJ, Hannibal MC, McMillin MJ, Gildersleeve HI, Beck AE, Tabor HK, Cooper GM, Mefford HC, Lee C, Turner EH, Smith JD, Rieder MJ, Yoshiura K, Matsumoto N, Ohta T, Niikawa N, Nickerson DA, Bamshad MJ, Shendure J. Exome sequencing identifies MLL2 mutations as a cause of Kabuki syndrome. Nat Genet. 2010a; 42(9):790-793. [PubMed: 20711175]

Ng SB, Buckingham KJ, Lee C, Bigham AW, Tabor HK, Dent KM, Huff CD, Shannon PT, Jabs EW, Nickerson DA, Shendure J, Bamshad MJ. Exome sequencing identifies the cause of a mendelian disorder. Nat Genet. 2010b; 42(1):30-35. [PubMed: 19915526]

Niemann S, Zhao C, Pascu F, Stahl U, Aulepp U, Niswander L, Weber JL, Muller U. Homozygous WNT3 mutation causes tetra-amelia in a large consanguineous family. Am J Hum Genet. 2004; 74(3):558-563. [PubMed: 14872406]

Nopoulos P, Richman L, Murray J, Canady J. Cleft palate and craniofacial conditions. Cleft Palate Craniofacial Journal. 2002; 39(1):123-124. [PubMed: 11772180]

Osoegawa K, Vessere GM, Utami KH, Mansilla MA, Johnson MK, Riley BM, L'Heureux J, Pfundt R, Staaf J, van der Vliet WA, Lidral AC, Schoenmakers EF, Borg A, Schutte BC, Lammer EJ, Murray JC, de Jong PJ. Identification of novel candidate genes associated with cleft lip and palate using array comparative genomic hybridisation. J Med Genet. 2008; 45(2):81-86. [PubMed: 17873121]

Packham EA, Brook JD. T-box genes in human disorders. Hum Mol Genet. 2003; 12(Spec No 1):R37-44. [PubMed: 12668595]

Pan Y, Zhang W, Du Y, Tong N, Han Y, Zhang H, Wang M, Ma J, Wan L, Wang L. Different roles of two novel susceptibility loci for nonsyndromic orofacial clefts in a Chinese Han population. Am J Med Genet A. 2011; 155A(9):2180-2185. [PubMed: 21834038]

Park JW, McIntosh I, Hetmanski JB, Jabs EW, Vander Kolk CA, Wu-Chou YH, Chen PK, Chong SS, Yeow V, Jee SH, Park BY, Fallin MD, Ingersoll R, Scott AF, Beaty TH. Association between 
IRF6 and nonsyndromic cleft lip with or without cleft palate in four populations. Genet Med. 2007; 9(4):219-227. [PubMed: 17438386]

Porter FD. Cholesterol precursors and facial clefting. J Clin Invest. 2006; 116(9):2322-2325. [PubMed: 16955133]

Quaderi NA, Schweiger S, Gaudenz K, Franco B, Rugarli EI, Berger W, Feldman GJ, Volta M, Andolfi G, Gilgenkrantz S, Marion RW, Hennekam RC, Opitz JM, Muenke M, Ropers HH, Ballabio A. Opitz G/BBB syndrome, a defect of midline development, is due to mutations in a new RING finger gene on Xp22. Nat Genet. 1997; 17(3):285-291. [PubMed: 9354791]

Rahimov F, Jugessur A, Murray JC. Genetics of nonsyndromic orofacial clefts. Cleft Palate Craniofacial Journal. 2012; 49(1):73-91. [PubMed: 21545302]

Rahimov F, Marazita ML, Visel A, Cooper ME, Hitchler MJ, Rubini M, Domann FE, Govil M, Christensen K, Bille C, Melbye M, Jugessur A, Lie RT, Wilcox AJ, Fitzpatrick DR, Green ED, Mossey PA, Little J, Steegers-Theunissen RP, Pennacchio LA, Schutte BC, Murray JC. Disruption of an AP-2alpha binding site in an IRF6 enhancer is associated with cleft lip. Nat Genet. 2008; 40(11):1341-1347. [PubMed: 18836445]

Reardon W, Winter RM, Rutland P, Pulleyn LJ, Jones BM, Malcolm S. Mutations in the fibroblast growth factor receptor 2 gene cause Crouzon syndrome. Nat Genet. 1994; 8(1):98-103. [PubMed: 7987400]

Richardson L, Venkataraman S, Stevenson P, Yang Y, Burton N, Rao J, Fisher M, Baldock RA, Davidson DR, Christiansen JH. EMAGE mouse embryo spatial gene expression database: 2010 update. Nucleic Acids Res. 2010; 38(Database issue):D703-709. [PubMed: 19767607]

Robertson SP, Twigg SR, Sutherland-Smith AJ, Biancalana V, Gorlin RJ, Horn D, Kenwrick SJ, Kim CA, Morava E, Newbury-Ecob R, Orstavik KH, Quarrell OW, Schwartz CE, Shears DJ, Suri M, Kendrick-Jones J, Wilkie AO. Group OP-sDCC. Localized mutations in the gene encoding the cytoskeletal protein filamin A cause diverse malformations in humans. Nat Genet. 2003; 33(4): 487-491. [PubMed: 12612583]

Roessler E, Belloni E, Gaudenz K, Jay P, Berta P, Scherer SW, Tsui LC, Muenke M. Mutations in the human Sonic Hedgehog gene cause holoprosencephaly. Nat Genet. 1996; 14(3):357-360. [PubMed: 8896572]

Roessler E, Du YZ, Mullor JL, Casas E, Allen WP, Gillessen-Kaesbach G, Roeder ER, Ming JE, Ruiz i Altaba A, Muenke M. Loss-of-function mutations in the human GLI2 gene are associated with pituitary anomalies and holoprosencephaly-like features. Proc Natl Acad Sci U S A. 2003; 100(23):13424-13429. [PubMed: 14581620]

Rogers CR, Weinberg SM, Smith TD, Deleyiannis FW, Mooney MP, Marazita ML. Anatomical basis for apparent subepithelial cleft lip: a histological and ultrasonographic survey of the orbicularis oris muscle. Cleft Palate Craniofacial Journal. 2008; 45(5):518-524. [PubMed: 18788877]

Shi M, Mostowska A, Jugessur A, Johnson MK, Mansilla MA, Christensen K, Lie RT, Wilcox AJ, Murray JC. Identification of microdeletions in candidate genes for cleft lip and/or palate. Birt Defects Res A Clin Mol Teratol. 2009; 85(1):42-51.

Shi M, Wehby GL, Murray JC. Review on genetic variants and maternal smoking in the etiology of oral clefts and other birth defects. Birth Defects Research Part C Embryo Today. 2008; 84(1):1629.

Sivertsen A, Wilcox AJ, Skjaerven R, Vindenes HA, Abyholm F, Harville E, Lie RT. Familial risk of oral clefts by morphological type and severity: population based cohort study of first degree relatives. BMJ. 2008; 336(7641):432-434. [PubMed: 18250102]

Slavotinek AM, Chao R, Vacik T, Yahyavi M, Abouzeid H, Bardakjian T, Schneider A, Shaw G, Sherr EH, Lemke G, Youssef M, Schorderet DF. VAX1 mutation associated with microphthalmia, corpus callosum agenesis, and orofacial clefting: the first description of a VAX1 phenotype in humans. Hum Mutat. 2012; 33(2):364-368. [PubMed: 22095910]

Snead MP, Yates JR. Clinical and Molecular genetics of Stickler syndrome. J Med Genet. 1999; 36(5): 353-359. [PubMed: 10353778]

Sotelo J, Esposito D, Duhagon MA, Banfield K, Mehalko J, Liao H, Stephens RM, Harris TJ, Munroe DJ, Wu X. Long-range enhancers on 8q24 regulate c-Myc. Proc Natl Acad Sci U S A. 2010; 107(7):3001-3005. [PubMed: 20133699] 
Sproule J. Hereditary nature of hare-lip. Br Med J. 1863; 1:412.

Stanier P, Moore GE. Genetics of cleft lip and palate: syndromic genes contribute to the incidence of non-syndromic clefts. Hum Mol Genet. 2004; 13(Spec No 1):R73-81. [PubMed: 14722155]

Sull JW, Liang KY, Hetmanski JB, Fallin MD, Ingersoll RG, Park J, Wu-Chou YH, Chen PK, Chong SS, Cheah F, Yeow V, Park BY, Jee SH, Jabs EW, Redett R, Scott AF, Beaty TH. Maternal transmission effects of the PAX genes among cleft case-parent trios from four populations. Eur $\mathrm{J}$ Hum Genet. 2009; 17(6):831-839. [PubMed: 19142206]

Suzuki K, Hu D, Bustos T, Zlotogora J, Richieri-Costa A, Helms JA, Spritz RA. Mutations of PVRL1, encoding a cell-cell adhesion molecule/herpesvirus receptor, in cleft lip/palate-ectodermal dysplasia. Nat Genet. 2000; 25(4):427-430. [PubMed: 10932188]

Tonkin ET, Wang TJ, Lisgo S, Bamshad MJ, Strachan T. NIPBL, encoding a homolog of fungal Scc2type sister chromatid cohesion proteins and fly Nipped-B, is mutated in Cornelia de Lange syndrome. Nat Genet. 2004; 36(6):636-641. [PubMed: 15146185]

Trew CJ. Sistens plura exempla palati deficientis. Nova Acta Physico-Medica Academiae caesarae. Leopoldion-Carolinae. 1757; 1:445-447.

Tsybovsky Y, Molday RS, Palczewski K. The ATP-binding cassette transporter ABCA4: structural and functional properties and role in retinal disease. Adv Exp Med Biol. 2010; 703:105-125. [PubMed: 20711710]

van den Boogaard MJ, Dorland M, Beemer FA, van Amstel HK. MSX1 mutation is associated with orofacial clefting and tooth agenesis in humans. Nat Genet. 2000; 24(4):342-343. [PubMed: 10742093]

Vieira AR. Genetic and environmental factors in human cleft lip and palate. Front Oral Biol. 2012; 16:19-31. [PubMed: 22759667]

Vieira AR, McHenry TG, Daack-Hirsch S, Murray JC, Marazita ML. A genome wide linkage scan for cleft lip and palate and dental anomalies. American Journal of Medical Genetics Part A. 2008; 146A(11):1406-1413. [PubMed: 18442096]

Vissers LE, van Ravenswaaij CM, Admiraal R, Hurst JA, de Vries BB, Janssen IM, van der Vliet WA, Huys EH, de Jong PJ, Hamel BC, Schoenmakers EF, Brunner HG, Veltman JA, van Kessel AG. Mutations in a new member of the chromodomain gene family cause CHARGE syndrome. Nat Genet. 2004; 36(9):955-957. [PubMed: 15300250]

Wagner T, Wirth J, Meyer J, Zabel B, Held M, Zimmer J, Pasantes J, Bricarelli FD, Keutel J, Hustert E, Wolf U, Tommerup N, Schempp W, Scherer G. Autosomal sex reversal and campomelic dysplasia are caused by mutations in and around the SRY-related gene SOX9. Cell. 1994; 79(6): 1111-1120. [PubMed: 8001137]

Wallis DE, Roessler E, Hehr U, Nanni L, Wiltshire T, Richieri-Costa A, Gillessen-Kaesbach G, Zackai EH, Rommens J, Muenke M. Mutations in the homeodomain of the human SIX3 gene cause holoprosencephaly. Nat Genet. 1999; 22(2):196-198. [PubMed: 10369266]

Wehby GL, Cassell CH. The impact of orofacial clefts on quality of life and healthcare use and costs. Oral Dis. 2010; 16(1):3-10. [PubMed: 19656316]

Wehby GL, Castilla EE, Goco N, Rittler M, Cosentino V, Javois L, McCarthy AM, Bobashev G, Litavecz S, Mariona A, Dutra G, Lopez-Camelo JS, Orioli IM, Murray JC. Description of the methodology used in an ongoing pediatric care interventional study of children born with cleft lip and palate in South America [NCT00097149]. BMC Pediatr. 2006; 6:9. [PubMed: 16563165]

Wehby GL, Murray JC. Folic acid and orofacial clefts: a review of the evidence. Oral Dis. 2010; 16(1):11-19. [PubMed: 20331806]

Wei K, Chen J, Akrami K, Galbraith GC, Lopez IA, Chen F. Neural crest cell deficiency of c-myc causes skull and hearing defects. Genesis. 2007; 45(6):382-390. [PubMed: 17523175]

Weinberg S, Naidoo SD, Bardi KM, Brandon CA, Neiswanger K, Resick JM, Martin RA, Marazita ML. Face shape of unaffected parents with cleft affected offspring: combining three-dimensional surface imaging and geometric morphometrics. Orthod Craniofac Res. 2009; 12(4):271-281. [PubMed: 19840279]

Weinberg SM, Maher BS, Marazita ML. Parental craniofacial morphology in cleft lip with or without cleft palate as determined by cephalometry: a meta-analysis. Orthod Craniofac Res. 2006; 9(1): 18-30. [PubMed: 16420271] 
Weinberg SM, Neiswanger K, Richtsmeier JT, Maher BS, Mooney MP, Siegel MI, Marazita ML. Three-dimensional morphometric analysis of craniofacial shape in the unaffected relatives of individuals with nonsyndromic orofacial clefts: a possible marker for genetic susceptibility. American Journal of Medical Genetics Part A. 2008; 146A(4):409-420. [PubMed: 18203157]

Weinberg SM, Parsons TE, Fogel MR, Walter CP, Conrad AL, Nopoulos P. Corpus callosum shape is altered in individuals with nonsyndromic cleft lip and palate. Am J Med Genet A. 2013; 161(5): 1002-1007. [PubMed: 23532928]

West JR, Blake CA. Fetal alcohol syndrome: an assessment of the field. Exp Biol Med. 2005; 230(6): 354-356.

Wilcox AJ, Lie RT, Solvoll K, Taylor J, McConnaughey DR, Abyholm F, Vindenes H, Vollset SE, Drevon CA. Folic acid supplements and risk of facial clefts: national population based casecontrol study. BMJ (Clinical Research Edition). 2007; 334(7591):464.

Wilkie AO, Slaney SF, Oldridge M, Poole MD, Ashworth GJ, Hockley AD, Hayward RD, David DJ, Pulleyn LJ, Rutland P, et al. Apert syndrome results from localized mutations of FGFR2 and is allelic with Crouzon syndrome. Nat Genet. 1995; 9(2):165-172. [PubMed: 7719344]

Yang J, Carmichael SL, Canfield M, Song J, Shaw GM. Socioeconomic status in relation to selected birth defects in a large multicentered US case-control study. Am J Epidemiol. 2008; 167(2):145154. [PubMed: 17947220]

Yildirim M, Seymen F, Deeley K, Cooper ME, Vieira AR. Defining predictors of cleft lip and palate risk. J Dent Res. 2012; 91(6):556-561. [PubMed: 22496123]

Yoshiura K, Machida J, Daack-Hirsch S, Patil SR, Ashworth LK, Hecht JT, Murray JC. Characterization of a novel gene disrupted by a balanced chromosomal translocation $\mathrm{t}(2 ; 19)$ (q11.2;q13.3) in a family with cleft lip and palate. Genomics. 1998; 54(2):231-240. [PubMed: 9828125]

Zanke BW, Greenwood CM, Rangrej J, Kustra R, Tenesa A, Farrington SM, Prendergast J, Olschwang S, Chiang T, Crowdy E, Ferretti V, Laflamme P, Sundararajan S, Roumy S, Olivier JF, Robidoux F, Sladek R, Montpetit A, Campbell P, Bezieau S, O'Shea AM, Zogopoulos G, Cotterchio M, Newcomb P, McLaughlin J, Younghusband B, Green R, Green J, Porteous ME, Campbell H, Blanche H, Sahbatou M, Tubacher E, Bonaiti-Pellie C, Buecher B, Riboli E, Kury S, Chanock SJ, Potter J, Thomas G, Gallinger S, Hudson TJ, Dunlop MG. Genome-wide association scan identifies a colorectal cancer susceptibility locus on chromosome 8q24. Nat Genet. 2007; 39(8): 989-994. [PubMed: 17618283]

Zankl A, Duncan EL, Leo PJ, Clark GR, Glazov EA, Addor MC, Herlin T, Kim CA, Leheup BP, McGill J, McTaggart S, Mittas S, Mitchell AL, Mortier GR, Robertson SP, Schroeder M, Terhal $\mathrm{P}$, Brown MA. Multicentric carpotarsal osteolysis is caused by mutations clustering in the aminoterminal transcriptional activation domain of MAFB. Am J Hum Genet. 2012; 90(3):494-501. [PubMed: 22387013]

Zhu JL, Basso O, Hasle H, Winther JF, Olsen JH, Olsen J. Do parents of children with congenital malformations have a higher cancer risk? A nationwide study in Denmark. Br J Cancer. 2002; 87(5):524-528. [PubMed: 12189550]

Zucchero TM, Cooper ME, Maher BS, Daack-Hirsch S, Nepomuceno B, Ribeiro L, Caprau D, Christensen K, Suzuki Y, Machida J, Natsume N, Yoshiura K, Vieira AR, Orioli IM, Castilla EE, Moreno L, Arcos-Burgos M, Lidral AC, Field LL, Liu YE, Ray A, Goldstein TH, Schultz RE, Shi M, Johnson MK, Kondo S, Schutte BC, Marazita ML, Murray JC. Interferon regulatory factor 6 (IRF6) gene variants and the risk of isolated cleft lip or palate. N Engl J Med. 2004; 351(8):769-780. [PubMed: 15317890]

\section{Biographies}

Elizabeth J. Leslie received her Ph.D. in Genetics from the University of Iowa in 2012, and is currently pursuing a postdoctoral fellowship in Craniofacial and Dental Genetics, and in Biomedical Informatics at the University of Pittsburgh.

Mary L. Marazita received her Ph.D. in Genetics from the University of North Carolina, Chapel Hill in 1980, followed by postdoctoral training in Craniofacial Biology at the 
University of Southern California (1980-1982), and American Board of Medical Genetics certification as a Ph.D. Medical Geneticist (1987). Following faculty positions at UCLA and the Medical College of Virginia, she is currently Director of the Center for Craniofacial and Dental Genetics, and Professor of Oral Biology, Human Genetics, Clinical and Translational Science, and Psychiatry at the University of Pittsburgh 


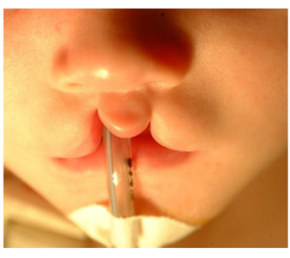

Figure $1 \mathrm{~A}$.

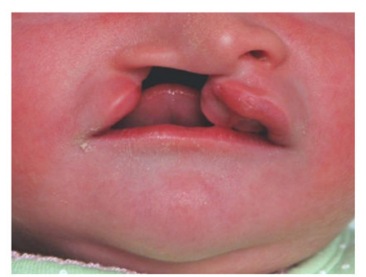

Figure 1B.

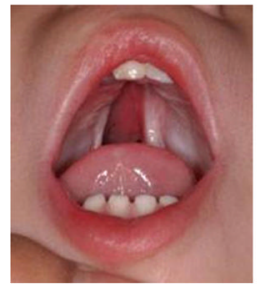

Figure 1C.

Figure 1.

Examples of Nonsyndromic Cleft Lip and Cleft Palate.

1A. Bilateral Cleft Lip Alone

1B. Unilateral Cleft Lip plus Cleft Palate

1C. Cleft Palate Alone

Images courtesy of FaceBase (www.FaceBase.org) 


\section{Table I}

Selected CL/P Syndromes with known genetic cause

\begin{tabular}{|c|c|c|c|}
\hline Syndrome & Cleft Type Observed & Gene & Reference \\
\hline Ankyloblepharon-ectodermal dysplasia-clefzting & $\mathrm{CL} / \mathrm{P}$ & TP63 & [McGrath et al., 2001] \\
\hline Apert & $\mathrm{CP}$ & $F G F R 2$ & [Wilkie et al., 1995] \\
\hline Bamforth-Lazarus & $\mathrm{CP}$ & FOXE1 & [Bamforth et al., 1989] \\
\hline Bartsocas-Papas & $\mathrm{CL} / \mathrm{P}$ & RIPK4 & $\begin{array}{r}\text { [Kalay et al., 2012; Mitchell et al., } \\
2012]\end{array}$ \\
\hline Branchio-oculo-facial & $\mathrm{CL} / \mathrm{P}$ & TFAP $2 A$ & [Milunsky et al., 2008] \\
\hline Campomelic dysplasia & $\mathrm{CP}$ & SOX9 & $\begin{array}{r}\text { [Foster } \text { et al., 1994; Wagner } \text { et al., } \\
1994]\end{array}$ \\
\hline CHARGE & $\mathrm{CP}$ & CHD7 & [Vissers et al., 2004] \\
\hline CLP ectodermal dysplasia & $\mathrm{CL} / \mathrm{P}$ & PVRL1 & [Suzuki et al., 2000] \\
\hline Cornelia de Lange & $\mathrm{CP}$ & $N I P B L$ & $\begin{array}{r}\text { [Krantz et al., 2004; Tonkin et al., } \\
2004]\end{array}$ \\
\hline Crouzon & $\mathrm{CP}$ & $F G F R 2$ & [Reardon et al., 1994] \\
\hline DiGeorge & $\mathrm{CP}$ & $T B X 1$ & [Packham and Brook 2003] \\
\hline Ectrodactyly-ectodermal dysplasia-clefting & $\mathrm{CL} / \mathrm{P}$ & $T P 63$ & [Celli et al., 1999] \\
\hline Familial gastric cancer and CLP & $\mathrm{CL} / \mathrm{P}$ & $\mathrm{CDH} 1$ & [Frebourg et al., 2006] \\
\hline Gorlin & $\mathrm{CL} / \mathrm{P}$ & PTCH1 & [Hahn et al., 1996; Johnson et al., 1996] \\
\hline Holoprosencephaly & $\mathrm{CL} / \mathrm{P}$ & GLI2 & [Roessler et al., 2003] \\
\hline Holoprosencephaly & $\mathrm{CL} / \mathrm{P}$ & SHH & [Roessler et al., 1996] \\
\hline Holoprosencephaly & $\mathrm{CL} / \mathrm{P}$ & SIX3 & [Wallis et al., 1999] \\
\hline Holoprosencephaly & $\mathrm{CL} / \mathrm{P}$ & $T G I F$ & [Gripp et al., 2000] \\
\hline Isolated cleft palate & $\mathrm{CP}$ & SATB2 & [FitzPatrick et al., 2003] \\
\hline Kabuki & $\mathrm{CL} / \mathrm{P}$ & $M L L 2$ KDM6A & [Lederer et al., 2012; Ng et al., 2010a] \\
\hline Kallmann & $\mathrm{CL} / \mathrm{P}$ & FGFRI & [Dode et al., 2003] \\
\hline Lethal and Escobar multiple pterygium & $\mathrm{CP}$ & CHRNG & [Morgan et al., 2006] \\
\hline Loeys-Dietz & $\mathrm{CP}$ & $T G F B R 1, T G F B R 2$ & [Loeys et al., 2005] \\
\hline Miller & $\mathrm{CP}$ & DHODH & [Ng et al., 2010b] \\
\hline Oculofaciocardiodental & $\mathrm{CP}$ & $B C O R$ & [Ng et al., 2004] \\
\hline Opitz G/BBB & $\mathrm{CL} / \mathrm{P}$ & MID1 & [Quaderi et al., 1997] \\
\hline Oro-facial-digital & $\mathrm{CL} / \mathrm{P}$ & GLI3 & [Johnston et al., 2010] \\
\hline Oro-facial-digital type 1 & $\mathrm{CL} / \mathrm{P}$ & OFD1 & [Ferrante et al., 2001] \\
\hline Otopalatodigital types 1 and 2 & $\mathrm{CP}$ & FLNA & [Robertson et al., 2003] \\
\hline Pierre Robin & $\mathrm{CP}$ & SOX9 & [Benko et al., 2009] \\
\hline Popliteal pterygium & $\mathrm{CL} / \mathrm{P}$ & IRF6 & [Kondo et al., 2002] \\
\hline Saethre-Chotzen & $\mathrm{CP}$ & TWIST1 & $\begin{array}{r}\text { [el Ghouzzi et al., 1997; Howard et al., } \\
1997]\end{array}$ \\
\hline Stickler type 1 & $\mathrm{CP}$ & COL2Al & [Snead and Yates 1999] \\
\hline Stickler type 2 & $\mathrm{CP}$ & COL11A1, COL11A2 & [Snead and Yates 1999] \\
\hline
\end{tabular}




\begin{tabular}{|l|c|l|r|}
\hline Syndrome & Cleft Type Observed & Gene & Reference \\
\hline Tetra-amelia with CLP & CL/P & WNT3 & [Niemann et al., 2004] \\
\hline Tooth agenesis with or without cleft & CL/P & $M S X 1$ & [van den Boogaard et al., 2000] \\
\hline Treacher Collins & CP & $T C O F 1$ & [Kondo et al., 2002] 1996] \\
\hline Van der Woude & CL/P & $I R F 6$ & [Braybrook et al., 2001] \\
\hline X-linked cleft palate and ankyloglossia & CP & $T B X 22$ & [Laumonnier et al., 2005] \\
\hline Siderius X-linked mental retardation & CL/P & $P H F 8$ &
\end{tabular}

CL- cleft lip

CP- cleft palate

CL/P- cleft lip with or without cleft palate 


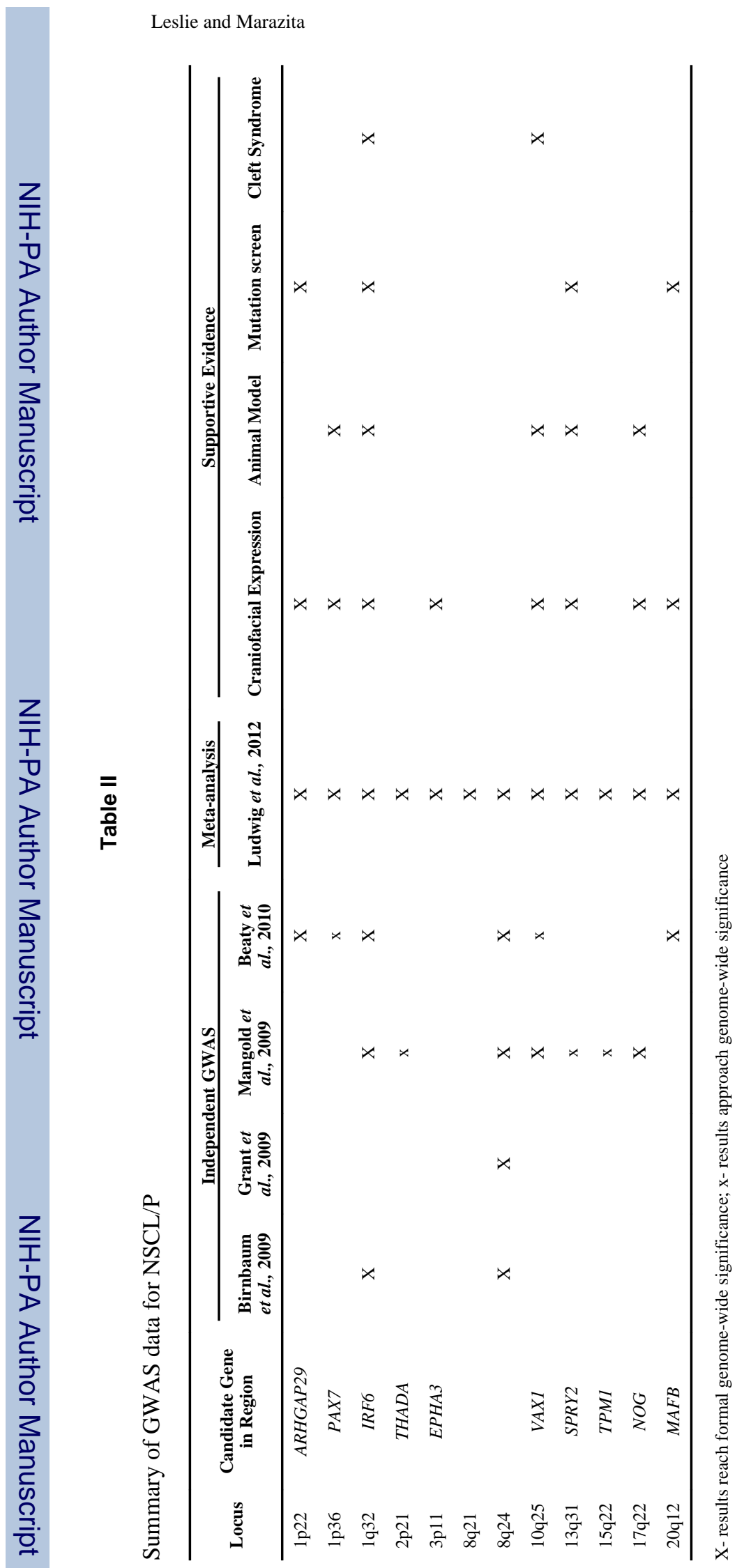

Am J Med Genet C Semin Med Genet. Author manuscript; available in PMC 2014 November 01. 